\title{
Corporate Cultural Responsibility and Shared Value in the Banking Sector. An Explorative Study in Italy
}

Preliminary communication _ DOI 10.22522/cmr20180129 _ received on 13 February 2018 UDK: 005.35: 008 336.71

\section{Valentina Martino}

Department of Communication and Social Research, Sapienza University of Rome, Italy.

Email: valentina.martino@uniroma1.it (corresponding author)

\section{Stefano Scarcella Prandstraller}

Department of Communication and Social Research, Sapienza University of Rome, Italy. Email: s.scarcella.prandstraller@gmail.com

\section{Abstract}

This paper aims to explore the emerging trends and strategic approaches promoted by Italian banks in the field of corporate cultural responsibility and communication. Based on a multi-case study approach, the research focuses on both the policies and operational activities carried out in the last decade by some of the most innovative players in the field of corporate arts management and communication, promoting an innovative logic of social sharing and stakeholder engagement around banks' art collections, events and digital platforms.

Keywords: corporate cultural communication, corporate cultural responsibility, corporate shared value, banking communication and PR, arts philanthropy, corporate social responsibility 


\section{Introduction}

Public relations strategies based on culture and arts are an internationally emerging phenomenon, which some scholars define "corporate cultural communication" (Martino, 2010, 2013) or "corporate cultural responsibility" (Azzarita et al., 2010). Such an approach sees companies including artistic activities, programmes, or even long-term policies in their own business strategies to strategically support corporate identity and reputation.

In the international context, the Italian case distinguishes itself traditionally for relevant investments by the banking sector and its own non-profit foundations (European Parliament, 2011; Omega, 2016; Wu, 2002). Indeed, in order to value their own roots and responsibility toward the territory, these organisations promote projects benefiting local communities especially in the artistic-cultural sector, which in Italy continues to absorb most bank foundations' investments in corporate social responsibility (ACRI, 2016).

In general, banks' PR and communications approach is experiencing an intense evolution nowadays, concerning both on- and off-line activities. Especially in the last decade, the banking sector has been facing a strong drive toward change and internationalisation, as well as a dramatic reputational crisis (Dell’Atti, Trotta, 2016; Pratt et al., 2011; Strauß, Vliegenthart, 2017; Xifra, Ordeix, 2009) after several scandals hitting the sector: among them, it is possible to remember in Italy the clamorous crash in 2013 of the Monte dei Paschi di Siena Bank, considered the oldest bank in the world, followed by the "four local banks" scandal in 2015 and the "Venetian" bank crisis in 2017.

In such a scenario, this paper aims to investigate the contemporary trends and approaches promoted in the field of corporate cultural responsibility and communication, by analysing several best practices and innovative experiences developed by some of the major players in the Italian banking sector. 


\section{Literature Review}

\subsection{Cultural Responsibility and Communication}

Corporate "social" or "public" responsibility, which originally emerged in the seventies (Carroll, 1977, 1979), was imposed on public and scientific attention especially in the nineties. Then, in the following decades the topic was institutionalised in Europe according to some specific definitions provided by the European Community (Scarcella Prandstraller, 2013).

In particular, the original CSR approach encompassed a voluntary integration of ethical causes in the mission of private companies (Commission of the European Communities, 2001) and, more recently, a more substantial responsibility for their own impact on society (European Community, 2011). In the international debate, such visions tend to be enriched by a more advanced paradigm today, addressed to promote corporate citizenship (Matten, Crane, 2005) and generate a "shared value" between companies and the community they belong to (Porter, Kramer, 2011).

While traditional CSR programmes focus mostly on reputation and have a limited connection to core business, the emerging approaches wish to be an integral part of a company's mission (Visser, 2013). Indeed, corporate shared value (CSV) involves creating profitability in a way that also generates well-being for society by addressing its needs in several ways: by reconceiving companies' products and markets, redefining productivity in the value chain and building supportive industry clusters around corporate locations (Porter, Kramer, 2011).

Since the shared value paradigm was defined, it no longer represents a pioneering practice nowadays, limited to a vanguard of entrepreneurs and companies, but a reality for a growing number of European companies, whose policies and practices are addressed to supporting strategic relationships and "alliances" with the community (Visser, 2013). In such a changing scenario, arts and culture tend to emerge, in Italy and abroad, as an ultimate expression of contemporary corporate responsibility and shared value when they are conceived not only as a pure economic investment, but as a community and civic one (Bulut, Bulut Yumrukaya, 2009; Civita, 2017; Regione Piemonte, Unioncamere Piemonte, 2014).

Cultural responsibility and communication (Azzarita et al., 2010; Martino, 2010) have been spreading in business strategies especially since the nineties and, in the new millennium, 
have demonstrated that they can stand against an economic crisis (Civita, 2017; European Parliament, 2011; Wu, 2002). If in past decades, in most European countries, corporate intervention in arts was generally limited to a niche of the business system (traditionally identified with major, state-owned corporations or "enlightened" patrons, first and foremost Olivetti), today it is acquiring a managerial logic: that of a strategic investment supporting the corporate mission (Bondardo, 2007; Martino, 2010, 2013), which is accessible to all companies to foster a return of both internal expertise and quality relationships with stakeholders (Schiuma, 2011a, 2011b).

\subsection{The Evolution of Banks' Cultural Policies and Communication}

In the Italian context, a capillary participation in the artistic-cultural sector is a distinctive expression of contemporary banking ethics (ABI, 1997; ACRI, 2016). Such a phenomenon is unique worldwide and boasts ancient roots, since it can be considered an inheritance of the Renaissance patronage tradition (when many noble families were also bankers) and, in particular, of a prestigious history of "patron-bankers" committed to commissioning and collecting arts and crafts (D’Orazio, 2016): a tradition that, over the centuries, has combined both private ostentation of prestige and contribution to the community, as well as the logic of economic investment and the brilliant intuition, ahead of its time, of a higher "added" (Zamagni, 2010) and "shared" value (Porter, Kramer, 2011) descending from corporate involvement in the arts.

Thanks to their ability to interpret genius loci and connect to cultural tradition of the territory, throughout their history banks have cultivated a special relationship with local communities, even when acting in a global business perspective. Indeed, today the Italian banking industry results second only to the state for the range of its own cultural policies and heritage (D’Orazio, 2016), since it is proud of some special records: among them, the promotion of excellent book editions, which would otherwise remain out of the market; the safeguarding of a huge artistic heritage which would risk to be sold and end up abroad; support for local cultural events and centres (museums, libraries, archives etc.), suffering from a chronic lack of financial resources; last but not least, the restitution to the public of architectural treasures and art crafts belonging to private collections.

A decisive role in supporting the cultural life of the country is played by foundations of banking origin (Civita, 2006; Leardini, Rossi, 2010; Tosolini, 2013). They are a widespread 
phenomenon in Italy, as well as in other Mediterranean countries (European Parliament, 2011), since they were instituted in 1990 by a national law aiming at separating the philanthropic and lending activities of banks in order to restructure the Italian credit system. Their CSR investments traditionally privilege the artistic-cultural sector, in 2016 concentrating about a third of both their overall budget (25.3\%) and interventions (34.5\%) all around the country, according to data provided by the Association of Italian Savings Banks and Foundations of Banking Origin (ACRI, 2017).

Such a prestigious tradition is undergoing a wider evolution today, concerning banks' marketing and PR strategies internationally. Indeed, since the eighties the banks' competitive environment has become more complex because of rising phenomena such as liberalisation, internationalisation and corporate mergers and acquisitions (Brioschi, 1999; Jensen, 1983); furthermore, in the last decade a dramatic spiral of financial crises and scandals has been hitting banks' reputational capital both in Italy and abroad (Pratt et al., 2011; Strauß, Vliegenthart, 2017; Xifra, Ordeix, 2009). In such a changing context, the banking industry has experimented a growing need for marketing and corporate communication strategies which should be specific for the financial market, to involve customers and other stakeholders by means of innovative off- and on-line activities (Ancarani, Musile Tanzi, 2012; Ki, 2013).

It is possible to register, on the one hand, a growing investment in internal marketing and communication strategies addressed to both managers and employees responsible for service quality and communication to the public (Incletolli, 2011); on the other, a strong inclination by banks toward promoting a direct and more empathetic dialogue with customers and other stakeholders, by means of a strategic combination of events throughout the country and new digital platforms. In particular, according to a national survey, in 2016 most Italian large (100\%) and small-medium banks (71\%) exercised an active presence in the most popular social networks, where they disseminated specific multimedia contents (ABI, KPMG, 2016). All these communication channels appear to be strategic not only to develop banking business and interacting with customers, but also to support corporate communication by experimenting a more involving, relational approach based on reputation and quality relationships with stakeholders (Argenti, 2009; Cornelissen, 2011; Fombrun, van Riel, 2004; Ki, Kim, Ledingham, 2015; Goodman, Hirsch, 2010; Grunig, Grunig, Dozier, 2002). 


\section{Research Questions and Methods}

From said scenario, this study investigates the contemporary evolution of cultural responsibility and communication strategies promoted by the banking industry in Italy. Some explorative research has been developed by combining a scientific literature review with a multi-case study, to focus on the most innovative trends distinguishing the Italian case compared both to the past and the international situation. In particular, two main research questions drive the study:

RQ1: In which ways is the specific Italian banks' approach to arts and culture evolving with respect to the past?

RQ2: What are the emerging contexts and communicative channels today which support Italian banks' cultural strategies?

The study is based on a review of the academic literature on PR and corporate communication. The theoretical framework includes publications and previous studies investigating the phenomenon of cultural communication emerging in Italy and abroad, especially during the last decade, as a strategic dimension of corporate responsibility and shared value strategies. The literature review has also examined specialised publications and statistical reports concerning the contemporary evolution of banks' communication, PR, and sustainability policies in Italy and abroad.

Field research was developed according to a multi-case study strategy (Stake, 1995; Yin, 2018), investigating a selected group of innovative experiences and best practices in the field whose example might inspire other banking organisations both in Italy and abroad. To this purpose, three different corporate case studies were conducted and especially addressed to identifying variables and connections grounded in empirical data (Glaser, Strauss, 1967), in order to focus on different approaches and experiences promoted by banks in Italy. Context analysis followed a multi-method approach, based on both the analysis of several documental sources (such as internal corporate materials, reports, communication documents and publications) and direct observations conducted by the authors themselves within corporate head offices, events and cultural centres. 
Furthermore, in addition to several informal meetings with the organisations investigated, five in-depth interviews were collected with managers and PR leaders employed in the organisations investigated from April to June 2018 (see Table 1). Interviews were recorded, transcribed with the formal permission of the interviewees, and analysed according to an interpretative approach (Hubermas, Miles, 2002).

Table 1. Selected organisations and interviewees in the research panel

\begin{tabular}{|c|c|c|c|}
\hline Organisation & Year of foundation & $\begin{array}{l}\text { Location in } \\
\text { Italy }\end{array}$ & Interviewees \\
\hline $\begin{array}{l}\text { Italian Banking } \\
\text { Association }\end{array}$ & 1919 & Rome & $\begin{array}{l}\text { Giovanni Porcari, Cultural } \\
\text { Designer at Cultural Relations } \\
\text { Office }\end{array}$ \\
\hline Intesa Sanpaolo Bank & 2007 & Turin & $\begin{array}{l}\text { Vittorio Meloni, Head of } \\
\text { External Relations }\end{array}$ \\
\hline Mediolanum Bank & 1982 & $\begin{array}{l}\text { Basiglio } \\
\text { (Milan) }\end{array}$ & $\begin{array}{l}\text { Stefano Pirrone, Senior Private } \\
\text { Manager and Responsible for } \\
\text { the corporate head office in } \\
\text { Padua } \\
\text { Gianluca Randazzo, Corporate } \\
\text { Social Responsibility Manager } \\
\text { Gianluigi Recarti, Consultant } \\
\text { and Expert in Public Relations } \\
\text { and Communication }\end{array}$ \\
\hline
\end{tabular}

\section{Findings}

The research investigated the cultural policies promoted by banks in Italy in recent years. The first and more explorative part of the study reports the coordination role played by the Italian Banking Association (ABI), as the major national network representing the sector and promoting a multi-year programme of cultural events and initiatives all over the country. Then, the second part of study focuses on two different corporate case histories: Intesa Sanpaolo Bank and Mediolanum Bank, distinguishing themselves as two of the most innovative contemporary players in the field of arts management and communication in Italy. 


\subsection{Italian Banking Association}

The Italian Banking Association (ABI), founded in 1919, is the main non-profit organisation representing the banking sector in Italy. The association is located in Rome and its mission is to defend the interests of affiliated banks and promote their economic and ethical development. In particular, its magazine "Rivista Bancaria" was launched in 1921 and also by means of several research activities, the association carries on a national monitoring of banks' culture and communication offering.

Since 2013 ABI has established a dedicated Cultural Relations office within its Corporate and Media Relations Department, promoting a specific action plan entitled Banks for Culture, best exploiting banks' culture and diffuse heritage to reinforce relationships with stakeholders such as institutions, media system, politics, families, schools and universities. The purpose is to coordinate, for the first time, banks' efforts for culture to reduce fragmentation and individualism of single local initiatives. For example, a recent national survey promoted by the association itself registered only in the two-year period 2013-2014 a sample of about 2,500 cultural projects, among which especially artistic exhibitions, concerts and educational activities promoted all over the country by both large and small-medium banks (D’Orazio, 2016).

To communicate the extraordinary artistic heritage of banks by making it accessible to the public at large, $\mathrm{ABI}$ has created several cultural platforms converging on a common purpose to reinforce dialogue with stakeholders and, in particular, local communities. Among the most long-lasting initiatives, a prestigious annual event is Invitation to the Palace: since its first edition in 2002, the appointment has made possible, every first Saturday of October, a special opening to the public of both the historical palaces and modern sites belonging to banks in Italy, offering free guided visits in their own workplaces. Furthermore, a digital map organised by region and city makes a virtual tour of this diffuse artistic heritage available on the web.

Among the other projects, it is possible to mention the Festival of Creative Culture, a programme of events that $\mathrm{ABI}$ has promoted every year in spring, since 2014, with the aim of bringing into contact arts and young people under 13 years old: several activities are dedicated to them and their families such as workshops, guided tours, exhibitions and shows. The festival's fourth edition involved, in April 2017, over 75 events in 50 Italian cities, following an annual common theme developed by affiliated banks in collaboration with schools, local associations and cultural institutions. 
In 2015, ABI also launched the project of a Virtual Museum of Italian Banks (MUVIR), involving a pilot group of some of the major banks in Italy. The initiative, still in progress today, aims to gather a huge permanent exhibition of the artistic heritage belonging to banks' private collections (paintings, sculptures, coins etc.). By means of a dedicated web portal, the museum wishes to exhibit a collection of over 300 thousands art crafts, digitalised and catalogued for the purpose.

ABI's commitment to promoting cultural publishing in the banking sector is also remarkable. In particular, in February 2015, a unique collection, dedicated to the precious publishing tradition carried on by banks in Italy, was created and opened to the public in the association's headquarters in the centre of Rome, in the Stables at Altieri Palace. The "Stefano Stiglienti" Library collects more than 12 thousand books from the second half of the eighteenth century especially in the fields of arts and territory, among which a relevant number of limited and valuable editions, and is still enriched over time with the new book productions from ABI's affiliates. The library participates in wider sector networks, such as the National Library System and the pole of cultural centres of Rome; its catalogue and major service information are also available on line.

\subsection{Intesa San Paolo Bank}

Intesa Sanpaolo Bank stands today as the leading banking group in Italy and one of the largest in Europe. Legally established in Turin (in a corporate skyscraper designed in 2015 by the architect Renzo Piano) and with its executive headquarters in Milan, it is the result of a merger between Intesa and the Sanpaolo IMI banks in 2007. Corporate commitment toward the artistic-cultural sector is rooted in the philanthropic tradition carried on by more than 250 pre-existing banks the group has absorbed over time, among which the ancient Bank of Naples (1539).

Following ABI's recommendations, Intesa Sanpaolo has established a dedicated Cultural Heritage Department, standing as one of the most brilliant players in the arts management and communication field in Italy. Corporate cultural policies converge today into a dedicated national "Culture Project", launched in 2012 and whose strong multidisciplinary and communication orientation distinguishes Intesa Sanpaolo's approach from the philanthropic one carried out by the major banks in Italy and abroad (Figure 1). 
In 2003 Intesa Sanpaolo established its own historical archive, of which its major site is located in Milan, to conserve the group's corporate memory and coordinate the local historical heritage of several absorbed banks. The bank also promotes a rich publishing activity in the fields of art, music, history and economy. In addition, it supports the preservation of Italian cultural heritage and offers access to its own ample artistic and architectural heritage.

In particular, since 1989, a corporate programme entitled “Restitutions” has restored more than one thousand artworks and monuments all around Italy and, since 2016, also abroad. Continual activities are developed in collaboration with public authorities, such as research and cataloguing of the art crafts, permanent exhibitions and events, loans and educational and communication services.

The bank also supports the arts through strategic partnerships with several cultural institutions and events, such as the Italian National Trust (FAI), the Teatro alla Scala in Milan, the International Book Fair of Turin. In 2015 Intesa Sanpaolo participated in the World Expo as official global partner, with a prestigious corporate pavilion and programme of events. In the same year, the bank financed the restoration of the house of the writer Alessandro Manzoni in Milan. It also sponsors cultural projects, among which the Vox Imago multimedia project promoting opera culture through a multimedia activity.

The group offers access to a wide-ranging architectural heritage as well as to its own art collections, resulting from the several corporate mergers and including approximately 20,000 artworks from archaeology to contemporary arts, with a precious collection of $19^{\text {th }}$ century painters and works of well-known modern artists such as Balla, Boccioni, De Chirico and Fontana. In order to make the bank's art collection accessible to the public at large, the “Galleries of Italy” project created a network among several corporate locations, transformed into exhibition centres and first opened in Vicenza (1999) and later, in Naples (2007) and Milan (2011).

In particular, the corporate gallery in Milan, located in the historical palace of the Commercial Bank of Italy in piazza Scala and requiring an entrance ticket, hosts two floors of exhibitive spaces hosting both the bank's permanent collection and temporary exhibitions: among them, the successful one presenting 120 paintings by the well-known artist Francesco Hayez received a public of 80,000 visitors overall from November 2015 to February 2016. Among the 
remarkable features, it is possible to mention several multimedia didactic and communication services, the highly differentiated exhibition spaces suggesting the idea of travel, and the annexed bookshop and coffee restaurant inviting the public to prolong their stay in the centre.

In 2016 Intesa Sanpaolo won, ex-aequo with Deutsche Bank, the first edition of the "Corporate Art Awards" promoted by the Luiss Business School of Rome, as the best corporate collection in Italy. In recent years, events and exhibitions of such extraordinary corporate heritage have extended also to the web by means of virtual tours, contests, and other initiatives aiming to engage the public; as well as to the major bank's branches all over the country, as part of a wider corporate project developing from $2014 \mathrm{a}$ friendlier banking service. With its corporate arts collections, the bank also participates in the pilot group of partners contributing to the creation of the Virtual Museum of Italian Banks (MUVIR), headed by ABI.

Last but not least, an educational mission, addressed to promote financial culture among families and young people, has animated several educational activities developed since 2008 in collaboration with schools, universities and research centres all around the country, as well as the opening of a Savings Museum in Turin in 2012.

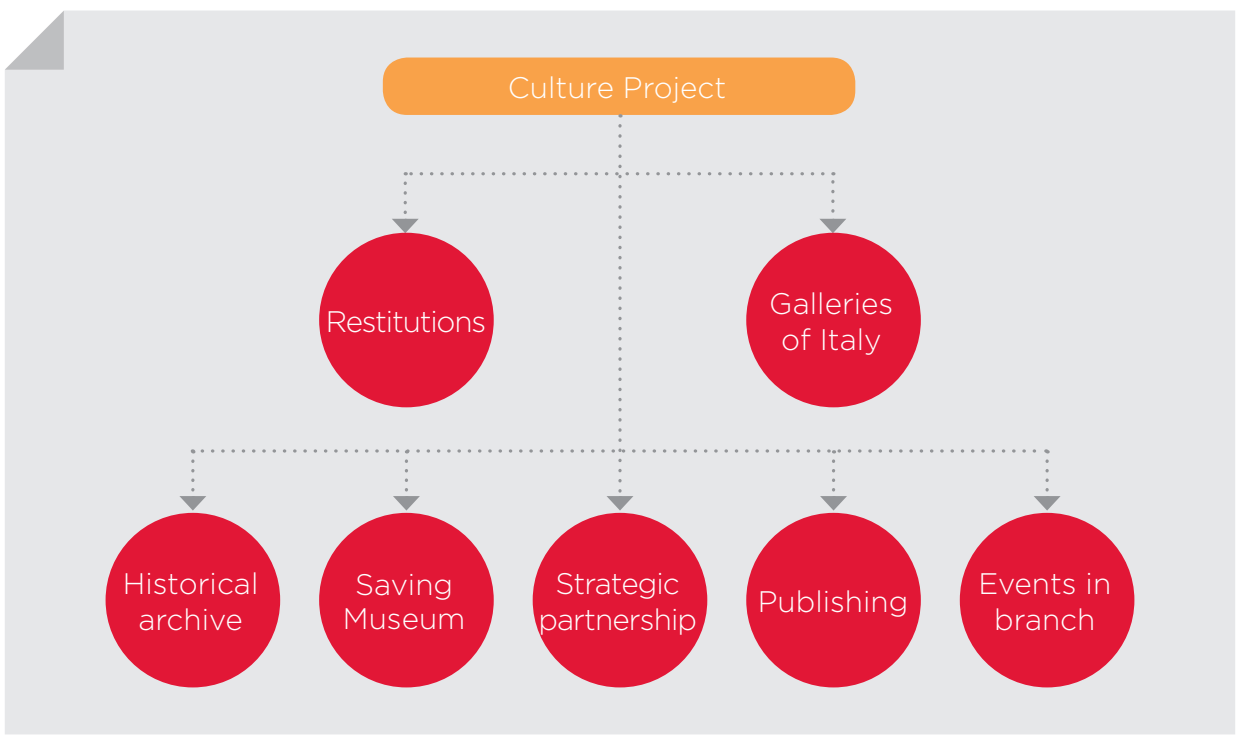

Figure 1. Intesa Sanpaolo Bank’s Culture Project 


\subsection{Mediolanum Bank}

Mediolanum Bank, legally established in Basiglio (Milan), originates from the Programma Italia SpA, the first national network offering global consultancy in the sector of savings and welfare, which was founded in 1982 by Ennio Doris in partnership with the Fininvest Group led by Silvio Berlusconi. In 1985 a company of investment funding was created, and in 1997 Programma Italia was transformed into Mediolanum Bank, to give life to an innovative Italian telematic bank integrating financial services into the many already offered to companies and private clients.

Policies concerning arts and culture have been part of the corporate strategy of Mediolanum Bank since the very beginning in 1998 and, by its founder, they are intended as a distinctive value. In particular, their corporate approach to culture is not limited to buying and treasuring artworks, but aims at valuing art and transforming it into a daily living experience for the bank's stakeholders by means of several activities developed over time.

Mediolanum Bank established a Corporate University providing courses in several subjects to employees and managers at different levels, together with a corporate museum opened in 2009 and representing the company's history. The corporate university aims to offer managers, personnel, clients and other stakeholders resources and tools to share corporate values and experiences; it organises events with the participation of experts and special guests, as well as programmes in different subjects.

Corporate policies for arts operate from a permanent centre in Padua, Casa Mediolanum, hosting both financial offices and a gallery exhibiting works of renowned artists, where exhibitions, presentations and other events are frequently organised. The innovative head office in Piazzetta Bussolin is the most relevant cultural project: inaugurated in 2014, nowadays it has become a pilot experiment for transforming other bank sites in the country into artistic locations. The facade is decorated with mosaics and every corridor, staircase and room contains artworks the bank acquired in its collection: they characterise the frame itself of the company's workplace, in the spirit of a diffuse museum where art is lived daily both by employees and clients as an emotional and inspiring experience.

To share the bank's artistic heritage, collective and personal exhibitions are promoted periodically and free guided visits are offered to external visitors. The gallery exhibits the 
works of both famous artists such as Hayez, Melotti, Zandomeneghi, Warhol and emerging ones, sometimes sharing the same exhibitive spaces. In particular, Mediolanum supports the career of about 2,000 young artists from different countries by promoting dedicated presentations, awards and contests, also offering them the chance to exhibit their works in regular exclusive events, which enrich corporate art collection and sites over time.

The corporate head office in Padua has also been promoted as a social operation on a large scale, by a massive intervention supporting the urban requalification of the degraded surrounding area and its restitution to the community. This action implied the rebuilding of social-economic tissue (since many professional studios and offices were attracted to the same area by the presence of the bank), as well as the restructuring of infrastructures and street furniture, and a massive insertion of artworks inside the urban landscape in a way allowing their public fruition. A similar operation of urban requalification, today in advanced state of implementation, concerns the degraded zone of Padua's waterways around the Piovego river, where a new Contemporary Art Museum scattered among the living tissue of the city, the Mediolanum Urban Gallery, will be opened.

Furthermore, Mediolanum participates in a network of corporate partnerships involving the Biennale Festival of Venice, Zabarella Palace Museum in Padua, Miart of Milan, Guggenheim Museum, and several other art centres and galleries in Italy and abroad, in order to promote joint initiatives and the mobility of artists.

The key asset of corporate social policies is, then, Mediolanum Foundation Onlus. Founded in 2002 to develop and follow up the main activities promoted in the social field, it provides a continuous fundraising from clients, the amount of which is doubled by the company, and promotes several humanitarian and social campaigns. The corporate foundation has no management costs, because the administrative work is guaranteed by the bank's personnel, and therefore the funds raised can be fully destined to humanitarian causes and projects. 


\section{Discussion}

The key findings of this study are discussed below also by reporting some excerpts from the interviews, to illustrate both the strategic approach (Section 5.1) and the major operational channels (Section 5.2) supporting the most innovative experiences of corporate arts communication and management promoted by Italian banks.

\subsection{From Arts Philanthropy to Business}

Arts and culture, animating a prestigious philanthropic tradition promoted by the banking system (ABI, 1997; Civita, 2006; D’Orazio, 2016), seem to arise as a key asset of Italian banks' corporate identity and PR strategy facing the contemporary state of crisis. Indeed, especially in the last decade, the community expects banks to invest in common values and heritage: "Today more than ever, arts and culture represent a natural evolving of richness towards ethics" (Pirrone, 2017).

Indeed, the banking system offers a privileged insight into the emerging relevance of reputation for business communication as a key resource assuring not only profitability, but the enduring itself of companies and brands (Argenti, 2009; Cornelissen, 2011; Fombrun, van Riel, 2004; Ki, Kim, Ledingham, 2015; Goodman, Hirsch, 2010; Grunig, Grunig, Dozier, 2002). On the one hand, reputation studies applied to the banking industry receive only marginal interest from scholars at the moment (Dell'Atti, Trotta, 2016); on the other, reputation is emerging today as one of the most valuable intangible assets for banks and financial firms because the services they provide are based on trust (Ki, 2013): a future benefit for customers, sustaining instead an information asymmetry at present. Furthermore, the whole banking sector is exposed nowadays to an ever more unstable financial and business climate, which makes it particularly sensitive to reputational risks and crisis (Pratt et al., 2011; Strauß, Vliegenthart, 2017; Xifra, Ordeix, 2009).

For such reasons, in the process of brand reputation building and management carried out by the banking sector a decisive role is played by opinion leaders and, in particular, by the information disseminated through the media (Dell'Atti, Trotta, 2016). Thus, also an emerging relevance of ethical and CSR strategies (Atakan-Duman, Ozdora-Aksak, 2014; Pratt et al., 2011), capable of promoting quality relationships with the strategic public as well as the circulation 
of positive news, data and contents concerning the banking industry and its players in the media agenda and in public opinion at large. Indeed, "in a period of crisis, social and cultural communication reveals itself particularly effective to dialogue with local communities and, in particular, with those countries' sectors facing difficulties and for which a bank can do something. From this point of view, cultural communication becomes a reputational asset which is today more important than ever.” (Meloni, 2017)

Since banks have to face a more complex and competitive environment (Ancarani, Musile Tanzi, 2012; Dell'Atti, Trotta, 2016), arts and culture rise as a corporate communication strategy supporting responsiveness and reputation also by representing "Made in Italy" identity and excellence (Martino, Lovari, 2017). Banks' corporate intervention extends from classical to contemporary arts, from performing to visual ones, from the restoration of ancient monuments and art crafts to the promotion of original artistic creations and experimentation by emerging artists. Corporate cultural policies also combine several approaches: not only traditional patronage and sponsorship, both generally implying a mere economic contribution to a cultural cause or institution, but also autonomous investment in original cultural projects and in-house events, as well as strategic and long-lasting partnerships with the major artistic institutions of the country (Bondardo, 2007; Martino, 2010; Martino, Herranz, 2016).

From this scenario and after a preliminary overview of ABI's action plan, the in-depth analysis of two corporate case histories helps to highlight the phenomenon under different profiles. The first, concerning a major bank with deep roots in the territory such as Intesa Sanpaolo, orients especially toward a corporate approach valuing an immense art collection, inherited over centuries from the pre-existing banks the group has absorbed over time. To this end, an innovative business and management approach has been improved, especially in the last five years, to support the major Italian bank's reaction to the reputational crisis of the sector, as well as the internationalisation of its business by a brilliant connection to the Made in Italy brand (Martino, Lovari, 2017). Differently, the second example refers to a young family bank, created ex novo its own corporate heritage by supporting emerging artists and local culture: such an approach seems to incline more traditionally toward internal and community relations, privileging primary stakeholders (employees, customers and the local area) to promote both organisational welfare in workplaces (Avallone, Paplomatas, 2005; Reiff Howarth, 2012) and urban regeneration around corporate sites. In both cases, however, art results no longer 
managed as a philanthropic matter, but rather as a strategic asset producing not a purely private value, but a community and "shared” one (Civita, 2017).

Unlike a traditional philanthropic approach, art is becoming today a strategic business itself, on which banks are experimenting innovative management and communication strategies supporting their own core activity and competing as equals with the major cultural institutions of the country. On the one hand, the extent and quality distinguishing banks' policies for arts nowadays can be considered as strictly subsequent to their rising exposition to crisis and changes (Porter, 1990; Verčič, Grunig, 2000); on the other, such critical context conditions assure banks a leading role in respect to other companies and business sectors. In particular, the banks' example is emblematic of the contemporary evolution of corporate communication towards reputation (Argenti, 2009; Cornelissen, 2011; Fombrun, van Riel, 2004; Goodman, Hirsch, 2010). Furthermore, it illustrates a progressive differentiation of corporate approaches in the artistic-cultural field (Martino, 2010), since companies are increasingly integrating arts and culture into their corporate mission by means of autonomous cultural events and policies (based, in general, on corporate collections or long-term partnerships), or even permanent corporate institutions (for instance, historical archives, museums and galleries, and other cultural centres).

\subsection{Corporate Art Collections, Events, and Digital Communication}

The findings of the study suggest that, especially in the last decade, Italian banks have been rediscovering the potentialities of arts and culture under a new profile: that of a strategic and relational asset, stimulating a process of innovation and value generation inside and outside organisations (Schiuma, 2011a, 2011b). Indeed, “today arts and culture are rediscovered by banks in Italy as alternative communication channels themselves, which however can be considered integral to national banking tradition from its origins about seven centuries ago. [...] Thus, in the banking sector, acute market competition expresses itself in an intense «cultural competition», producing a great benefit for the community.” (Porcari, 2017)

In particular, an innovative logic of "sharing” animates the rise of a new managerial and participatory patronage today not treasuring arts, simply conceived as an economic corporate investment increasing over time, but on the contrary valuing its social and relational value 
by making corporate heritage accessible to segments of the public which are both traditional and innovative, as evidenced by the following excerpt: "The point is to not only treasure the arts, but to do culture. We have chosen to live art, not to close it in a vault." (Recarti, 2017)

As especially the very brilliant experience of Intesa Sanpaolo suggests, some banks seem to transform themselves into real cultural business, developing specialised professional profiles and skills to improve a specific service and brands offered in the artistic-cultural sector. To this purpose, just the choice to invest strategically in communication can make the difference for those companies traditionally committed to arts:

"We select valuable cultural projects also offering communication opportunities. The difference with other banks, in Italy and abroad, is the commitment and extent in communicating our own corporate heritage and events. Of course, in the artistic-cultural sector quality contents are due, but they must be brought to the public. After all, in Italy there is a very intense competition for cultural proposals: thus, communication makes the difference by making arts and culture an integral part of corporate identity, to reinforce public perception and reputation.” (Meloni, 2017)

Thus considered, this study has investigated the major operational channels supporting cultural management and communication strategies adopted by Italian banks, also in the light of their contemporary evolution. The research findings suggest three decisive fields in which banks usually play their cultural strategies: corporate art collections, variously including both classic and contemporary art crafts; events and exhibitions, promoting access to corporate heritage on the territory, as well as its spectacularisation for the public; not least, digital communication, combining the use of corporate websites and the new participatory platforms offered by social media.

Together with banks' corporate architectures, art collections continue to represent today, as in the past, the key asset of cultural communication policies (Harris, Reiff Howarth, 2014). Banks' collections stand historically as one of the most ancient examples of corporate heritage, significantly contributing to making corporate arts the most stable branch of the global arts industry (Reiff Howarth, 2012). On the one hand, corporate collections are traditionally used for internal purposes to symbolise core values to employees (Kottasz et al., 2008; Reiff Howarth, 2012). On the other, they are increasingly valued and opened to the external public in different ways: within corporate workplaces, redefined as artistic sites themselves where 
internal stakeholders can daily live a cultural experience together with customers and business partners; as well as in specific corporate museums or galleries; and even turning to external centres and prestigious artistic locations.

Furthermore, the creation itself of a corporate art collection is being transformed into a real communication event (Bondardo, 2002; Martino, 2010), by promoting for instance contests and other PR special initiatives (such as Mediolanum's programme for young artists); in the same spirit, exhibits and other happenings are periodically launched to animate corporate heritage and its management (Martino, 2013). Cultural events and exhibits are also used as an ideal context to develop and reinforce cooperation with cultural institutions at both the local and national level: in this way, they can act as a sort of social "elevator" for companies, capable of accelerating the acquisition of prestigious social relationships which could be precluded otherwise.

Last but not least, digital channels represent a third fundamental platform for corporate responsibility and cultural communication strategies (Atakan-Duman, Ozdora-Aksak, 2014; Ozdora-Aksak, Atakan-Duman, 2015). Indeed, today digitalisation offers a historical occasion for companies to discover a logic of cultural "sharing" and experiment innovative languages (ABI, KPMG, 2016), communicating corporate heritage on both corporate sites and social networks to also engage new and younger segments of the public.

\section{Conclusions}

According to the scenario described by several national surveys in the sector, the major findings of this study suggest that, in a time of crisis, Italian banks are rediscovering arts and culture as a strategic investment in both societal value and Made in Italy's reputation, in this way renovating a long and prestigious patronage tradition they have carried on over centuries. From such a point of view, arts and culture represent an exemplary field in which to cultivate a corporate shared value (Porter, Kramer, 2011), capable of combining the logic of both an economic investment (that animated the creation of banks' art collections in the past) and a social one (according to a traditional philanthropic commitment, usually entrusted to foundations of banking origin).

Indeed, diffuse cultural heritage belonging to banks arises as a corporate asset to be valued and communicated to the public, in this way promoting an innovative logic of social sharing 
and stakeholder engagement (Kang, 2014; Taylor, Kent, 2014) around corporate artistic collections, events and digital platforms. On the one hand, the several experiences previously examined in-depth can help explore the potential of arts and culture when they do not work as a tactical tool of marketing branding, but as a strategic platform for both business innovation and quality long-term relationships with the strategic public (Schiuma, 2011a, 2011b). On the other hand, Italian banks' policies aimed at reinforcing a strategic connection with arts and culture, which are today recognised internationally as the most distinctive expression and real "quintessence" of Italian identity (Martino, 2013).

Thus, the investigation of cultural communication and responsibility strategies promoted by banks in Italy also suggests some relevant practical and social implications. In particular, the banking industry offers a benchmarking model for organisations in other business contexts and countries, since it suggests innovative approaches to cultivate value for both companies and society. Furthermore, banks' cultural policies help to highlight the specificity distinguishing communication and PR strategies in Italy: indeed, today more than ever, they are oriented toward the promotion of cultural contents and values especially by those brands called on to compete internationally and represent Italian excellence.

The study can be also considered explorative and presents some limitations. In particular, the limited number of case histories reviewed does not consider the innovative experiences launched by other major banks (among which, in particular, Unicredit Bank in Milan), as well as by a multitude of local ones. To evaluate similarities and original features distinguishing the Italian state of art, a further step of the research could develop a punctual international comparison with those countries characterised by a deep-rooted philanthropic tradition, among which the USA, the UK and Germany (Wu, 2002), as well as with the ones where banks' patronage tradition is very relevant, such as Spain (European Parliament, 2011; Martino, Herranz, 2016). Furthermore, at the theoretical level, a more systematic framing of the topic would be desirable within the international debate on CSR and its contemporary trends, especially considering the contribution of institutional theories (Campbell, 2007).

Indeed, according to the findings discussed on the previous pages, once more the crisis reveals itself to be an opportunity for companies to discover an innovative logic of responsibility and stakeholder engagement, which at the same time could be integral to corporate mission and identity. For those Italian banks committed to arts, it means no more traditional philanthropy or sponsorship, but a strategic bet on innovation and Made in Italy's reputation. 


\section{Acknowledgements}

For their professional evidence, special thanks go to: Vittorio Meloni, past Head of External Relations at Intesa Sanpaolo Bank, and Giovanni Porcari, Cultural Designer at ABI's Cultural Relations Office. For Mediolanum Bank, we are also grateful to Stefano Pirrone, Senior Private Manager and Responsible for the corporate seat in Padua, Gianluca Randazzo, Corporate Social Responsibility Manager, and Gianluigi Recarti, Consultant and Expert of Public Relations and Communication. The conceptualisation and writing of the paper are the result of a common work by the authors. The attribution is the following: Valentina Martino is author of sections 4 (4.3 excluded) and 5; Stefano Scarcella Prandstraller wrote sections 2, 3, and 4.3. The introduction and the conclusion sections were co-written. This work was supported by Sapienza University of Rome.

\section{Reference List}

- ABI (1997). Ricerca sulle sponsorizzazioni culturali delle banche. Roma: Bancaria Editrice.

- ABI, KPMG (2016). Banche e social media. Retrieved from www.abi.it. 26 June 2018.

- ACRI (2017). Ventiduesimo Rapporto sulle Fondazioni di origine bancaria. Roma: Associazione di Fondazioni e di Casse di Risparmio SpA.

- Ancarani, F., Musile Tanzi, P. (Eds.). (2012). Il marketing per le banche e le assicurazioni. Milano: Egea.

- Argenti, P. A. (2009). Corporate Communication. Boston: McGraw-Hill 1994.

- Atakan-Duman, S., Ozdora-Aksak, E. (2014). The role of corporate social responsibility in online identity construction. Public Relations Review, 40 (5), 862-864.

- Avallone, F., Paplomatas, A. (2005). Salute organizzativa. Milano: Raffaello Cortina.

- Azzarita, V., De Bartolo, P., Monti, S., Trimarchi, M. (2010). Cultural social responsibility. Milano: Franco Angeli.

- Bondardo (Ed.). (2007). Impresa e cultura in Italia. Milano: Touring.

- Bondardo (Ed.). (2002). Collezionare arte. Milano: Il Sole24Ore, Milano.

- Brioschi, E. T. (1999). Marketing e comunicazione. Milano: Vita \& Pensiero.

- Bulut, D., Bulut Yumrukaya, C. (2009). Corporate social responsibility in culture and art. Management of Environmental Quality, 20, 311-320.

- Campbell, J. L. (2007). Why would corporations behave in socially responsible ways? Academy of Management Review, 3, 946-967.

- Carroll, A. B. (1977). Managing Corporate Social Responsibility. Boston: Little \& Brown.

- Carroll, A. B. (1979). A Three-Dimensional Conceptual Model of Corporate Social Responsibility. Academy of Management Review, 4, 497-505.

- Civita (Ed.). (2006). Fondazioni bancarie e cultura. Milano: Sperling \& Kupfer.

- Civita (2017). Dalla CSR alla “Corporate Cultural Responsibility”. Retrieved from www.civita.it. 26 June 2018.

- Commission of the European Communities (2001). Promoting a European framework for Corporate Social Responsibility. Green Paper, DOC/01/9.

- Cornelissen, J. (2011). Corporate Communication. London: Sage.

- D’Orazio, C. (2016). La cultura delle banche oggi. Bologna: il Mulino.

- Dell'Atti, S., Trotta, A. (Eds.) (2016). Managing Reputation in The Banking Industry. Cham: Springer.

- European Community (2011). A renewed EU strategy 2011-14 for Corporate Social Responsibility. COM (2011) 681

- European Parliament (2011). Encouraging private investment in the cultural sector. Committee on Culture and Education. Retrieved from http://bookshop.europa.eu/it/. 26 June 2018.

- Fombrun, C. J., van Riel, C. B. M. (2004). Fame and fortune. Upper Saddle River, NJ: Prentice Hall Financial Times. 
- Glaser, B., Strauss, A. (1967). The discovery of grounded theory: Strategies for qualitative research. Chicago: Adline.

- Goodman, M. B., Hirsch, P. B. (2010). Corporate communication. New York: Peter Lang.

- Grunig, L. A., Grunig, J. E., Dozier, D. M. (2002). Excellence in public relations and communication management. NJ - Lawrence Erlbaum Associates: Mahwah.

- Harris, P., Reiff Howarth, S. (2014). A Celebration of Corporate Art Programmes Worldwide. London: Wapping Arts Trust.

- Hubermas, M. A., Miles, M. B. (2002). The Qualitative Researcher's Companion. London: Sage.

- Incletolli, M. (2011). La comunicazione interna delle banche italiane. Roma: ABI.

- Jensen, A.W. (1983). The status of public relations in major U.S.banks. Public Relations Review, 9 (2), 53-64.

- Kang, M. (2014). Understanding public engagement. Journal of Public Relations Research, 26 (5), 399-416.

- Ki, E.-J. (2013). A model of an organization-public relationship for the banking industry. Public Relations Review, 39 (3), $216-218$.

- Ki, E.-J., Kim, J.-N., Ledingham J. A. (Eds.). (2015). Public Relations As Relationship Management (2nd ed.). New York: Routledge.

- Kottasz, R., Bennett, R., Savani, S., Ali-Choudhury, R. (2008). The role of corporate art in the management of corporate identity. Corporate Communications, 13, 235-254.

- Leardini, C., Rossi, G. (2010). Fondazioni bancarie, arte e cultura. Milano: Franco Angeli.

- Martino, V. (2010). La comunicazione culturale d’impresa. Milano: Guerini.

- Martino, V. (2013). Dalle storie alla storia d'impresa. Acireale-Roma: Bonanno.

- Martino, V., Herranz de la Casa, J. M. (2016). Arts and strategic communication in Italy and Spain. Tafter Journal, 86.

- Martino, V., Lovari, A. (2017), Sharing Made in Italy. Intesa Sanpaolo Bank’s cultural communication around World Expo 2015. In: J. VanSlyke Turk, J. Valin (Eds.), Public Relations Case Studies from around the World (2nd ed.). New York: Peter Lang.

- Matten, D., Crane, A. (2005). Corporate citizenship: Toward an extended theoretical conceptualization. Academy of Management Review, 30 (1), 166-179.

- Meloni, V. (2017). Personal communication.

- Omega (2016). Comparative Country Analysis on Business-Art Cooperation. Yaşar University. Retrieved from http://omega. yasar.edu.tr. 26 June 2018.

- Ozdora-Aksak, E., Atakan-Duman, S. (2015). The online presence of Turkish banks. Public Relations Review, 41 (1), 119-128.

- Pirrone, S. (2017). Personal communication.

- Porcari, G. (2017). Personal communication.

- Porter, M. E. (1990). The Competitive Advantage of Nations. New York: Free Press.

- Porter, M. E., Kramer, M. R. (2011). Create shared value. Harvard Business Review, 89, 62-77.

- Pratt, C. B., Ademosu, E. A., Adamolekun, W., Alabi, L., Carr, R. L. (2011). Managing a crisis of confidence in Nigeria’s banking and financial industry. Public Relations Review, 37 (1), 71-73.

- Recarti, G. (2017). Personal communication.

- Regione Piemonte, Unioncamere Piemonte (2014). CSR e cultura. Retrieved from www.csrpiemonte.it. 26 June 2018.

- Reiff Howarth, S. (2012). The Silent Partner. Belleair Bluffs - FL: The Humanities Exchange.

- Scarcella Prandstraller, S. (Ed.). (2013). Teorie e tecniche della responsabilità sociale d'impresa. Roma: Di Virgilio.

- Schiuma, G. (2011a). The Value of Arts for Business. Cambridge - UK: Cambridge University Press.

- Schiuma, G. (Ed.) (2011b). Managing Knowledge Assets and Business Value Creation in Organizations. Measures and Dynamics. Hershey - PA: IGI-GLOBAL.

- Stake, R. E. (1995). The Art of Case Study Research. Thousand Oaks: Sage.

- Strauß, N., Vliegenthart, R. (2017). Reciprocal influence? Investigating implicit frames in press releases and financial newspaper coverage during the German banking crisis. Public Relations Review, 43 (2), 392-405.

- Taylor, M., Kent, M. L. (2014). Dialogic engagement: Clarifying foundational concepts. Journal of Public Relations Research, 26 (5), 384-398

- Tosolini, M. M. (2013). Fondazioni bancarie e nuova economia della cultura. Venezia: Marsilio.

- Verčič, D., Grunig, J. E. (2000). The origins of public relations theory in economics and strategic management. In: D. Moss, D. Verčič, G. Warnaby (Eds.). Perspectives on public relations research. London: Routledge.

- Visser, W. (2013). The Age of Responsibility: CSR 2.0 and the new DNA of business. London: Wiley.

- Xifra, J., Ordeix, E. (2009). Managing reputational risk in an economic downturn. Public Relations Review, 35 (4), 353-360.

- Wu, C.-T. (2002). Privatizing culture. London: Verso.

- Yin, R. K. (2018). Case study research and Applications: Design and methods. Newbury Park, CA: Sage.

- Zamagni, S. (Ed.) (2010). Il valore aggiunto culturale - Special Issue. Paradoxa. 4. 


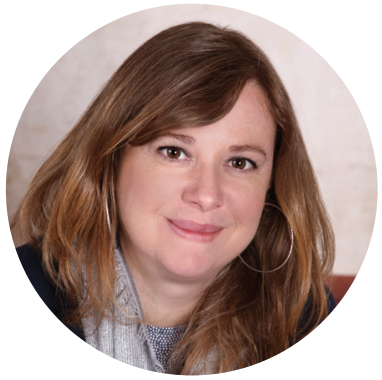

\section{Valentina Martino}

Valentina Martino, $\mathrm{PhD}$ in communication, is an assistant professor in cultural and communicative processes at the Department of Communication and Social Research, Sapienza University of Rome, where she teaches corporate communication. Since 2001 she has taught and conducted research in the areas of corporate and cultural communication, university communication and innovation, cultural consumptions. Her work has been published in national and international books and journals such as in particular Public Relations Review, International Journal of Strategic Communication, Tafter Journal.

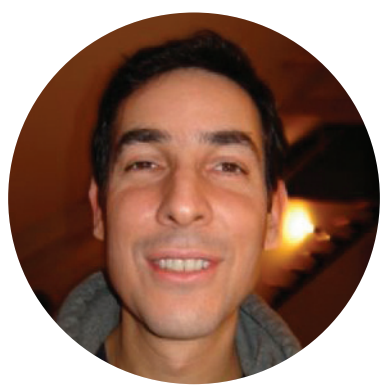

\section{Stefano Scarcella} Prandstraller

Stefano Scarcella Prandstraller, lawyer and sociologist, assistant professor of political sociology, former public manager and organizational consultant, author of many social researches and publications, has the Diploma in Public Relations and Reputation Management of the London School of Public Relations. He teaches from 2010 Public Relations and Corporate Social Responsibility in the Master Course in Organization and Marketing for Corporate Communications, Department of Communication and Social Research, Sapienza University of Rome. 